\title{
E-SERVICE QUALITY OF INTERNET BASED BANKING USING COMBINED FUZZY AHP AND FUZZY TOPSIS
}

\author{
Aşkın Özdă̆oğlu, Mehmet Emre Güler
}

Original scientific paper

Many researchers have used service quality scales for measuring service quality of banking sector including e-banking. Technology and technological tools are rapidly changed and every household has computers, pads and smartphones. They also get used to make banking operations with computers, pads or smartphones. In this study, we employed a fuzzy based prioritization using AHP and TOPSIS methods to the e-banking service quality indicators. The survey was carried out with the banking specialists and managers in both public and private banks inTurkey. The results provide helpful information for both web designers and internet users for developing and using the e-banking.

Keywords: fuzzy AHP; fuzzy TOPSIS; internet based banking; service quality

Kvaliteta e-usluge bankarstva temeljenog na Internetu kombiniranjem fuzzy AHP i fuzzy TOPSIS

Izvorni znanstveni rad

Mnogi su istraživači koristili mjerila za određivanje kvalitete usluga u bankarstvu uključujući e-bankarstvo. Tehnologija i tehnološki alati se brzo mijenjaju i svako kućanstvo ima računala, podloge i pametne telefone. Ljudi se navikavaju na obavljanje bankarskih poslova računalom ili pametnim telefonom. U ovom smo radu istraživali fuzzy AHP i TOPSIS metode u određivanju pokazatelja kvalitete u uslugama e-bankarstva. Istraživanje se provelo sa stručnjacima i menadžerima u bankarstvu u državnim i privatnim bankama u Turskoj. Rezultati su korisni i za web-dizajnere i korisnike interneta u razvoju i primjeni e-bankarstva.

Ključne riječi: bankarstvo temeljeno na Internetu; fuzzy AHP; fuzzy TOPSIS; kvaliteta usluge

\section{Introduction}

Services are located in all areas of our lives. For instance, we use communication and transportation service almost every day. Also we go to the bank for financial operation or go to the supermarket to meet daily needs and so on. All of these services and others are widely used depending on developments in information technology; the importance of services in our lives is increasing every day. On the other hand, in the service industry, the performance indicators are very important such as productivity, quality, efficiency, customer satisfaction. However, measurement of performance in service businesses because of the characteristics of services is not very easy.

For competitive survival, companies are focusing on areas in their operations that might give them an edge over their competitors. A key area has been the delivery of high levels of service quality [12]. During the past few decades service quality has become a major area of attention to practitioners, managers and researchers owing to its strong impact on business performance, lower costs, customer satisfaction, customer loyalty and profitability $[6,8,13 \div 17]$. Many researchers have defined the service quality and they identified the construct of it. In the literature the subject on how consumers perceive the service a company provides has been studied extensively, as evidenced by the research literature [11]. From an academic perspective McKenzie [11] cited in the literature from Cronin et al. (1994) and Zeithaml (2000) that has explored the theoretical framework and conceptualization of the construct, and from a practitioner standpoint, the linkages between providing high quality service and attaining superior firm performance. In this study, the service quality models are listed and explained. In the following sections, the employed methodology as the Fuzzy AHP and TOPSIS and the hierarchical model are explained with the numerical example and then the results are discussed in the final section.

\section{Service quality models}

Measuring service quality has so many difficulties for service providers. The reason for these difficulties is the unique characteristics of service such as inseparability, intangibility, perishability and heterogeneity. Many of researchers have developed the scales for measuring the quality of retail service. Seth et al. [14] discuss these scales in their study. These scales are listed in Tab. 1.

\section{Methodology used}

Many of the researchers measure the service quality by using these scales; especially SERVQUAL has been used in a number of studies $[1,9,10,18]$. In this paper, a systematic and practical methodology is developed and presented for the assessment of internet banking among many alternatives based on fuzzy models using linguistic variables.

The sample study of the methodology has been carried out with internet bank specialists. First of all a literature review is done on the criteria for the evaluation of internet banking. Hierarchical E-Servqual model has been used for evaluation.

Moreover, the list of banks is gathered and a question form is prepared asking the pair wise comparison and evaluation of each criterion for each bank based on fuzzy AHP and fuzzy TOPSIS, respectively.

The first phase of the methodology consists of weighting the hierarchical criteria set via fuzzy-AHP method so that the weights are calculated in a pair wise comparison manner which is the advantage of AHP 
method. In the second phase, the alternative banks are evaluated by considering each criterion in the bottom level of the criteria set. The evaluation process is carried out according to TOPSIS methodology which depends on linguistic variables and fuzzy logic.

TOPSIS methodology concerns the distances of each alternative evaluation from negative ideal solution and positive ideal solution. Thus, the results of the solution show the closeness of each alternative that represents the importance among others. There exist two reasons to use
TOPSIS model in the evaluation phase instead of any AHP method; when there are so many alternatives to be compared, then AHP method may generate inconsistency problem which is approved by so many studies in literature. The second reason is the complexity of comparison process; because alternatives should be evaluated more often than criteria set, the higher the number of alternatives, the higher the complexity. Instead of that, it would be more practical to use TOPSIS which includes linguistic evaluations based on fuzzy logic.

Table 1 Service Quality Models [14]

\begin{tabular}{|c|c|c|}
\hline Author & Scale Name & $\begin{array}{l}\text { Description } \\
\end{array}$ \\
\hline Grönross, 1984 & $\begin{array}{l}\text { Technical and functional quality } \\
\text { model }\end{array}$ & $\begin{array}{l}\text { The quality of service is measured by three components: Technical quality, } \\
\text { functional quality and image. }\end{array}$ \\
\hline Parasuraman et. al., 1985 & GAP model & $\begin{array}{l}\text { They identified five gaps and developed the scales based on these gaps. According } \\
\text { to this model the service quality depends on differences between perceptions and } \\
\text { expectations. }\end{array}$ \\
\hline Haywood-Farmer, 1988 & Attribute service quality model & $\begin{array}{l}\text { According to this model, quality of service is very high when it meets customer } \\
\text { preferences and expectations. }\end{array}$ \\
\hline Brogowicz et. al., 1990 & Synthesized model of service quality & $\begin{array}{l}\text { The purpose of this model is to identify the dimensions associated with service } \\
\text { quality in a traditional managerial framework of planning, implementation and } \\
\text { control. }\end{array}$ \\
\hline Cronin and Taylor, 1992 & Performance only model & $\begin{array}{l}\text { The authors investigated the conceptualization and measurement of service quality } \\
\text { and its relationship with consumer satisfaction and purchase intentions. }\end{array}$ \\
\hline Mattson, 1992 & Ideal value model of service quality & $\begin{array}{l}\text { This model identified that the expectation is treated as belief about having desired } \\
\text { attributes as the standard for evaluation. }\end{array}$ \\
\hline Teas, 1993 & $\begin{array}{l}\text { Evaluated performance and normed } \\
\text { quality model }\end{array}$ & $\begin{array}{l}\text { The author proposed two frameworks for service quality. One of them is evaluated } \\
\text { performance and other is normed quality model. }\end{array}$ \\
\hline Berkley and Gupta, 1994 & IT alignment model & $\begin{array}{l}\text { This model links the service and the information strategies of the organization. } \\
\text { According to the model, relationship between service quality and information } \\
\text { system is very important so that strategies for both must be tightly coordinated and } \\
\text { aligned. }\end{array}$ \\
\hline Dabholkar, 1996 & Attribute and overall affect model & $\begin{array}{l}\text { Both attribute model and overall affect model expected service quality would } \\
\text { influence intentions to use technology-based self-service option. }\end{array}$ \\
\hline Spreng and Mackoy, 1996 & $\begin{array}{l}\text { Model of perceived service quality } \\
\text { and satisfaction }\end{array}$ & $\begin{array}{l}\text { The model highlights the effect of expectations, perceived performance desires, } \\
\text { desired congruency and expectation disconfirmation on overall service quality and } \\
\text { customer satisfaction. }\end{array}$ \\
\hline Philip and Hazlett, 1997 & PCP attribute model & $\begin{array}{l}\text { According to the model, every service consist of PCP (pivotal, core, peripheral) } \\
\text { attributes where the vast majority of dimensions and concepts which have thus far } \\
\text { been used to define service quality. }\end{array}$ \\
\hline Sweney et. al., 1997 & $\begin{array}{l}\text { Retail service quality and perceived } \\
\text { value model }\end{array}$ & $\begin{array}{l}\text { Model } 1 \text { highlights that in addition to product quality and price perceptions, } \\
\text { functional service quality and technical service quality perceptions both directly } \\
\text { influence value perceptions. Model } 2 \text { highlights that in addition functional service } \\
\text { quality perceptions directly influence consumers' willingness to buy. }\end{array}$ \\
\hline Oh, 1999 & $\begin{array}{l}\text { Service quality, customer value and } \\
\text { customer satisfaction model }\end{array}$ & $\begin{array}{l}\text { The model provides evidence that customer value has a significant role in } \\
\text { customer's post-purchase decision-making process. It is an immediate antecedent } \\
\text { to customer satisfaction and repurchases intentions. }\end{array}$ \\
\hline Dabholkar et. al., 2000 & Antecedents and mediator model & $\begin{array}{l}\text { A comprehensive model of service quality includes an examination of its } \\
\text { antecedents, consequences, and mediators to provide a deeper understanding of } \\
\text { conceptual issues related to service quality. }\end{array}$ \\
\hline Frost and Kumar, 2000 & Internal service quality model & $\begin{array}{l}\text { The authors have developed an internal service quality model based on the } \\
\text { concept of GAP model (Parasuraman et al., 1985). The model evaluated the } \\
\text { dimensions, and their relationships, that determine service quality among internal } \\
\text { customers and internal suppliers within a large service organization. }\end{array}$ \\
\hline $\begin{array}{l}\text { Soteriou and Stavrinides, } \\
2000\end{array}$ & Internal service quality DEA model & $\begin{array}{l}\text { The authors presented a service quality model that can be used to provide } \\
\text { directions to a bank branch for optimal utilization of its resources. The model does } \\
\text { not aim to develop the service quality measures, it rather guides how such } \\
\text { measures can be incorporated for service quality improvements. }\end{array}$ \\
\hline $\begin{array}{l}\text { Broderick and } \\
\text { Vachirapornpuk, } 2002\end{array}$ & Internet banking model & This study proposes and tests a service quality model of internet banking. \\
\hline Zhu et. al., 2002 & IT-based model & $\begin{array}{l}\text { This model highlights the importance of information technology (IT)-based } \\
\text { service options. The model attempts to investigate the relationship between IT- } \\
\text { based services and customers' perceptions of service quality. }\end{array}$ \\
\hline Santos, 2003 & Model of service quality & This study proposes a conceptual model of e-service quality with its determinants. \\
\hline
\end{tabular}

The mathematical formulations for phase 1 and phase 2 are:

Phase 1: Criteria Importance Weighting: FuzzyAHP Methodology

To apply the process depending on the hierarchy, according to the method of Chang's (1992) extent analysis, each criterion is taken and extent analysis for each criterion, $g_{i}$; is performed. Therefore, $m$ extent analysis values for each criterion can be obtained by using the following notation [7]:

$$
M_{g_{i}}^{1}, M_{g_{i}}^{2}, M_{g_{i}}^{3}, M_{g_{i}}^{4}, M_{g_{i}}^{5}, \ldots, M_{g_{i}}^{m},
$$


where $g_{i}$ is the goal set $(i=1,2,3,4,5, \ldots, n)$ and all the $M_{g_{i}}^{j}(j=1,2,3,4,5, \ldots, m)$ are Triangular Fuzzy Numbers (TFNs). The steps of Chang's analysis can be given as in the following:

Step 1: The fuzzy synthetic extent value $\left(S_{i}\right)$ with respect to the $i^{\text {th }}$ criterion is defined as the following Eq. (1).

$$
S_{i}=\sum_{j=1}^{m} M_{g_{i}}^{j} \otimes\left[\sum_{i=1}^{n} \sum_{j=1}^{m} M_{g_{i}}^{j}\right]^{-1}
$$

To obtain Eq. (2):

$$
\sum_{j=i}^{m} M_{g_{i}}^{j}
$$

perform the "fuzzy addition operation" of $m$ extent analysis values for a particular matrix given in Eq. (3) below, at the end step of calculation, new $(l, m, u)$ set is obtained and used for the next:

$$
\sum_{j=1}^{m} M_{g_{i}}^{j}=\left(\sum_{j=1}^{m} l_{j}, \sum_{j=1}^{m} m_{j}, \sum_{j=1}^{m} u_{j}\right)
$$

where $l$ is the lower limit value, $m$ is the most promising value and $u$ is the upper limit value.

To obtain the following Eq. (4):

$$
\left[\sum_{i=1}^{n} \sum_{j=1}^{m} M_{g_{i}}^{j}\right]^{-1}
$$

perform the "fuzzy addition operation" of $M_{g_{i}}^{j}(j=1,2$, $3,4,5, \ldots, m)$ values given as Eq. (5):

$$
\sum_{i=1}^{n} \sum_{j=1}^{m} M_{g_{i}}^{j}=\left(\sum_{i=1}^{n} l_{i}, \sum_{i=1}^{n} m_{i}, \sum_{i=1}^{n} u_{i}\right)
$$

and then compute the inverse of the vector in the Eq. (6) such that

$$
\left[\sum_{i=1}^{n} \sum_{j=1}^{m} M_{g_{i}}^{j}\right]^{-1}=\left(\frac{1}{\sum_{i=1}^{n} u_{i}}, \frac{1}{\sum_{i=1}^{n} m_{i}}, \frac{1}{\sum_{i=1}^{n} l_{i}}\right) .
$$

\section{Step 2: The degree of possibility of} (7)

$M_{2}=\left(1_{2}, m_{2}, u_{2}\right) \geq M_{1}=\left(l_{1}, m_{1}, u_{1}\right)$ is defined as Eq.

$$
V\left(M_{2} \geq M_{1}\right)=\sup _{y \geq x}\left[\min \left(\mu_{M_{1}}(x), \mu_{M_{2}}(y)\right)\right]
$$

and $x$ and $y$ are the values on the axis of membership function of each criterion. This expression can be equivalently written as given in Eq. (8) below:

$$
V\left(M_{2} \geq M_{1}\right)= \begin{cases}1, & \text { if } m_{2} \geq m_{1}, \\ 0, & \text { if } l_{1} \geq u_{2}, \\ \frac{l_{1}-u_{2}}{\left(m_{2}-u_{2}\right)-\left(m_{1}-l_{1}\right)} & \text { otherwise, }\end{cases}
$$

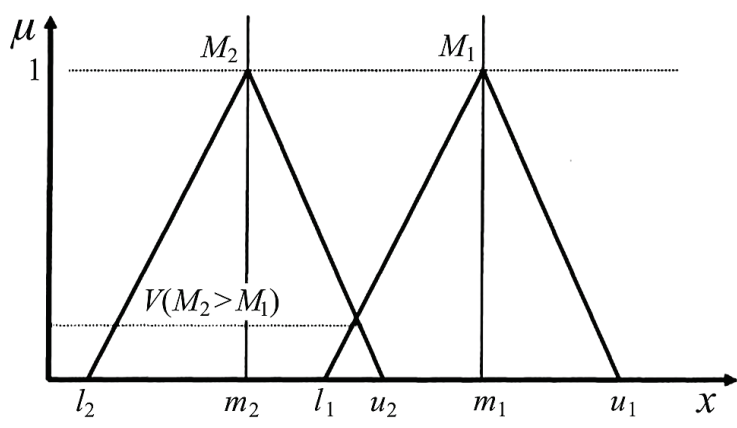

Figure 1 The intersection between $M_{1}$ and $M_{2}$ [19]

where $d$ is the highest intersection point $\mu_{M_{1}}$ and $\mu_{M_{2}}$ (see Fig. 1) [19].

To compare $M_{1}$ and $M_{2}$ we need both the values of $V\left(M_{2} \geq M_{1}\right)$ and $V\left(M_{1} \geq M_{2}\right)$ :

Step 3.The degree possibility for a convex fuzzy number to be greater than $k$ convex fuzzy numbers $M_{i}(i=$ $1,2,3,4,5, \ldots, k)$ can be defined by Eq. (9):

$V\left(M \geq M_{1}, M_{2}, M_{3}, M_{4}, M_{5}, M_{6}, \ldots, M_{k}\right)=V\left[\left(M \geq M_{1}\right)\right.$ and $\left(M \geq M_{2}\right)$ and $\left(M \geq M_{3}\right)$ and $\left(M \geq M_{4}\right)$ and $\ldots$ and $(M \geq$ $\left.\left.M_{\mathrm{k}}\right)\right]=\min V\left(M \geq M_{i}\right), i=1,2,3,4,5, \ldots, k$.

Assume the expression in Eq. (10) is:

$d^{l}\left(A_{i}\right)=\min V\left(S_{i} \geq S_{k}\right)$

For $k=1,2,3,4,5, \ldots, n ; k \neq i$. Then the weight vector is given by Eq. (11):

$W^{l}=\left(d^{l}\left(A_{1}\right), d^{l}\left(A_{2}\right), d^{l}\left(A_{3}\right), d^{l}\left(A_{4}\right), d^{l}\left(A_{5}\right), \ldots, d^{l}\left(A_{n}\right)\right)^{\mathrm{T}}$

where $A_{i}(i=1,2,3,4,5,6, \ldots, n)$ are $n$ elements.

Step 4.Via normalization, the normalized weight vectors are given in Eq. (12) below:

$W=\left(d\left(A_{1}\right), d\left(A_{2}\right), d\left(A_{3}\right), d\left(A_{4}\right), d\left(A_{5}\right), \ldots, d\left(A_{n}\right)\right)^{\mathrm{T}}$,

where $W$ is non-fuzzy numbers.

To evaluate the questions, people only select the related linguistic variable, then for calculations they are converted to the following scale including triangular fuzzy numbers developed by [4] and generalized for such analysis as given in Tab. 2 .

Table 2 TFN Values [20]

\begin{tabular}{|l|c|}
\hline \multicolumn{1}{|c|}{ Statement } & TFN \\
\hline Absolute & $(7 / 2,4,9 / 2)$ \\
\hline Very strong & $(5 / 2,3,7 / 2)$ \\
\hline Fairly strong & $(3 / 2,2,5 / 2)$ \\
\hline Weak & $(2 / 3,1,3 / 2)$ \\
\hline Equal & $(1,1,1)$ \\
\hline
\end{tabular}


By using these linguistic statements and given in Tab. 2 , criteria set are evaluated with the equations given in phase 1 (Eqs. (1) $\div(12)$ ) weight of each criterion is obtained and so that the weights can be used in TOPSIS methodology, they are converted to trapezoidal fuzzy number such as $(\mathrm{a}, \mathrm{a}, \mathrm{a}, \mathrm{a})$.

\section{Ratings}

Phase 2: TOPSIS and Linguistic Variables for

By considering this main concept of TOPSIS model is implemented according to the following steps:

1) Normalize the evaluation matrix: $x_{i j}$ is the evaluation matrix $\boldsymbol{R}$ of alternative $i$ under the evaluation criterion $j$. After normalization, the elements of matrix $R$ are converted into $r_{i j}$. Normalization is carried out by one of the methods which convert them into the numerical value, i.e. between $0 \div 1$, according to the characteristics of the problem [2].

2) Construct the weighted normalization matrix according to the values determined for each criterion. These weights $\left(w_{i j}\right)$ can be obtained by any method such as eigenvector, AHP, fuzzy numbers, linear programming models, etc., then these weight vector is multiplied by normalized matrix $R$ to obtain the weighted normalized matrix $v_{i j}$.

3) Determine the negative and positive ideal solutions.

4) Calculate the separation measure. This measure is selected among the measures for calculating the distances. This can be an Euclidean distance [3] or vertex distance [2].

5) Calculate the negative closeness to the ideal solution. The relative closeness of the $i^{\text {th }}$ alternative with respect to the ideal solution is calculated by negative distance over total distance.

6) Rank the priority: a set of alternatives is sorted according to descending order of relative closeness.

Fuzzy triangular and trapezoidal numbers are used to evaluate each bank alternative. The linguistic variable for evaluation lies between "very poor" and "very good", the membership function set is given in Fig. 2, and as an example, the linguistic variable "Very Good (VG) " can be represented as $(8,9,9,10)$, the membership function of which is given in Eq. (13):

$\mu_{\text {Very Good }}(x)=\left\{\begin{array}{ll}0, & x<8 \\ \frac{x-8}{9-8}, & 8 \leq x \leq 9 \\ 1, & 9 \leq x \leq 10\end{array}\right.$.

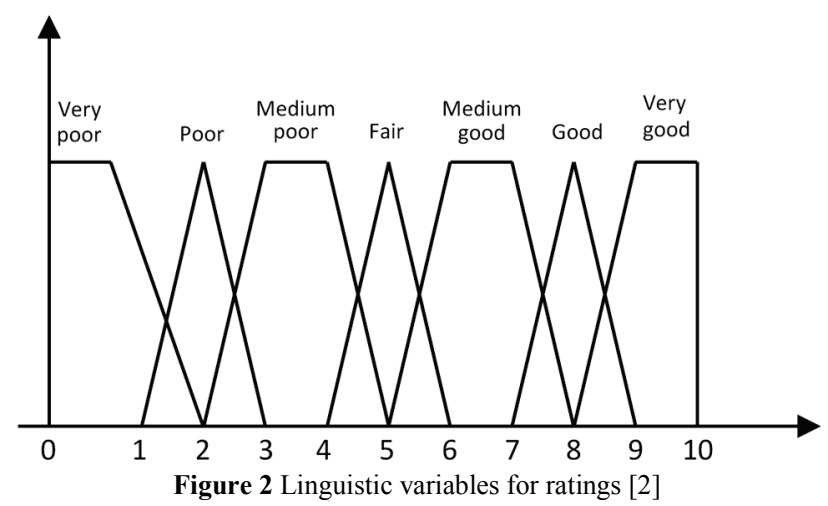

In fact, evaluation of internet banking is a multiplecriteria decision-making problem, which may be described by means of the following sets [2]:

(1) a set of $K$ users called $E=\left\{D_{1} ; D_{2} ; \ldots ; D_{K}\right\}$

(2) a set of $m$ possible bank alternatives called $A=\left\{A_{1}\right.$; $\left.A_{2} ; \ldots ; A_{m}\right\}$

(3) a set of $n$ criteria, $C=\left\{C_{1} ; C_{2} ; \ldots ; C_{n}\right\}$ with which internet banking performances are measured;

(4) a set of performance ratings of $A_{i}(i=1 ; 2 ; \ldots ; m)$ with respect to criteria $C_{j}(j=1 ; 2 ; \ldots ; n)$, called $X=\left\{x_{i j} ; i=1\right.$; $2 ; \ldots ; m ; j=1 ; 2 ; \ldots ; n\}$

Assume that a decision group has $K$ decision makers, and the fuzzy rating of each decision-maker $D_{k}(k=1 ; 2$; $\ldots, K)$ can be represented as a positive trapezoidal fuzzy number $\widetilde{R}_{k}(k=1 ; 2 ; \ldots ; K)$ with membership function $\mu_{\widetilde{R}_{k}}(x)$. A good aggregation method should consider the range of fuzzy rating of each decision-maker. It means that the range of aggregated fuzzy rating must include the ranges of all decision-makers' fuzzy ratings. Let the fuzzy ratings of all decision makers be trapezoidal fuzzy numbers $\widetilde{R}_{k}=\left(a_{k} ; b_{k} ; c_{k} ; d_{k}\right), k=1 ; 2 ; \ldots ; K$. Then the aggregated fuzzy rating can be defined as $\widetilde{R}=(a ; b ; c ; d)$, $k=1 ; 2 ; \ldots ; K$. Eqs. (14) to (17) shows the detailed computations:

where

$a=\min _{k}\left\{a_{k}\right\}$

$c=\frac{1}{K} \sum_{k=1}^{K} c_{k}$

$$
\begin{aligned}
& b=\frac{1}{K} \sum_{k=1}^{K} b_{k} \\
& d=\max _{k}\left\{d_{k}\right\}
\end{aligned}
$$

After the ratings are aggregated into one matrix normalized weighted matrix is constructed by calculating Eq. (18):

$V_{i j}=w_{i j} \times r_{i j}$

As mentioned before, weight of each criterion is calculated using Fuzzy-AHP method which produces crisp weights through fuzzy numbers. Thus, in order to aggregate weights with ratings, weights are assumed as trapezoidal fuzzy numbers which have equal values $(a=b$ $=c=d$ ). Then rating matrix is multiplied by weight matrix and finally weighted normalized matrix is obtained.

According to the weighted normalized fuzzy-decision matrix, normalized positive trapezoidal fuzzy numbers can also approximate the elements $\widetilde{v}_{i j}, \forall i, j$. Then, the fuzzy positive-ideal solution (FPIS, $A^{*}$ ) and fuzzy negative-ideal solution (FNIS, $A^{-}$) can be defined as $A^{*}=\left(\widetilde{v}_{1}^{*}, \widetilde{v}_{2}^{*}, \ldots, \widetilde{v}_{n}^{*}\right), \quad A^{-}=\left(\widetilde{v}_{1}^{-}, \widetilde{v}_{2}^{-}, \ldots, \widetilde{v}_{n}^{-}\right), \quad$ where the values can be calculated by Eqs. (19) and (20):

$\widetilde{v}_{j}^{*}=\max _{i}\left\{v_{i j 4}\right\}$

and

$\tilde{v}_{j}^{-}=\min _{i}\left\{v_{i j 1}\right\}$, 
The distance of each alternative (internet banking) from $\mathrm{A}^{*}$ and $\mathrm{A}^{-}$can be currently calculated with Eqs. $(21) \div(22):$

$$
\begin{aligned}
& d_{i}^{*}=\sum_{j=1}^{n} d_{v}\left(\widetilde{v}_{i j}, \widetilde{v}_{j}^{*}\right), \quad i=1,2, \ldots, m \\
& d_{i}^{-}=\sum_{j=1}^{n} d_{v}\left(\widetilde{v}_{i j}, \widetilde{v}_{j}^{-}\right), \quad i=1,2, \ldots, m
\end{aligned}
$$

where $d_{v}(.,$.$) is the vertex distance measurement between$ two trapezoidal fuzzy numbers that is calculated by Eq. (23):

$$
d_{v}(\widetilde{m}, \widetilde{n})=\sqrt{\frac{\left(m_{1}-n_{1}\right)^{2}+\left(m_{2}-n_{2}\right)^{2}+\left(m_{3}-n_{3}\right)^{2}+\left(m_{4}-n_{4}\right)^{2}}{4}} .
$$

A closeness coefficient is defined to determine the ranking order of all possible s once $d_{i}^{*}$ and $d_{i}^{-}$of each banks $A_{i}(i=1 ; 2 ; \ldots ; m)$ has been calculated. The closeness coefficient represents the distances to the fuzzy positive-ideal solution $\left(A^{*}\right)$ and the fuzzy negative-ideal solution $\left(A^{-}\right)$simultaneously by taking the relative closeness to the fuzzy positive-ideal solution. The closeness coefficient $\left(C C_{i}\right)$ of each alternative (banks) is calculated in Eq. (24):

$$
C C_{i}=\frac{d_{i}^{-}}{d_{i}^{*}+d_{i}^{-}}, \quad i=1,2, \ldots, m
$$

It is clear that $C C_{i}=1$ if $A_{i}=A^{*}$ and $C C_{i}=0$ if $A_{i}=$ $A^{-}$. In other words, bank $A_{i}$ is closer to the FPIS $\left(A^{*}\right)$ and farther from FNIS $\left(A^{-}\right)$as $C C_{i}$ approaches to 1. According to the descending order of $C C_{i}$, the ranking order of all banks is determined and the best one among a set of feasible banks is selected. For evaluation process, approval status for each alternative is defined in Tab. 3 which can also be used for further evaluation when a decision is required for any bank.

Table 3 Approval status [2]

\begin{tabular}{|l|l|}
\hline \multicolumn{1}{|c|}{ Closeness coefficient $\left(C C_{i}\right)$} & \multicolumn{1}{c|}{ Evaluation status } \\
\hline$C C_{i} \in[0 ; 0,2)$ & Do not recommend \\
\hline$C C_{i} \in[0,2 ; 0,4)$ & Recommend with high risk \\
\hline$C C_{i} \in[0,4 ; 0,6)$ & Recommend with low risk \\
\hline$C C_{i} \in[0,6 ; 0,8)$ & Approved \\
\hline$C C_{i} \in[0,8 ; 1,0)$ & Approved and preferred \\
\hline
\end{tabular}

\section{Model explanation}

First step of our model is to determine the web site evaluation criteria of e-banking. In e-sq measurement of e-banking web sites, the objective is to determine the best e-banking service delivery performance among the most preferable public and private banks of Turkey. Figure 3 depicts the hierarchy of the e-banking website service quality model.

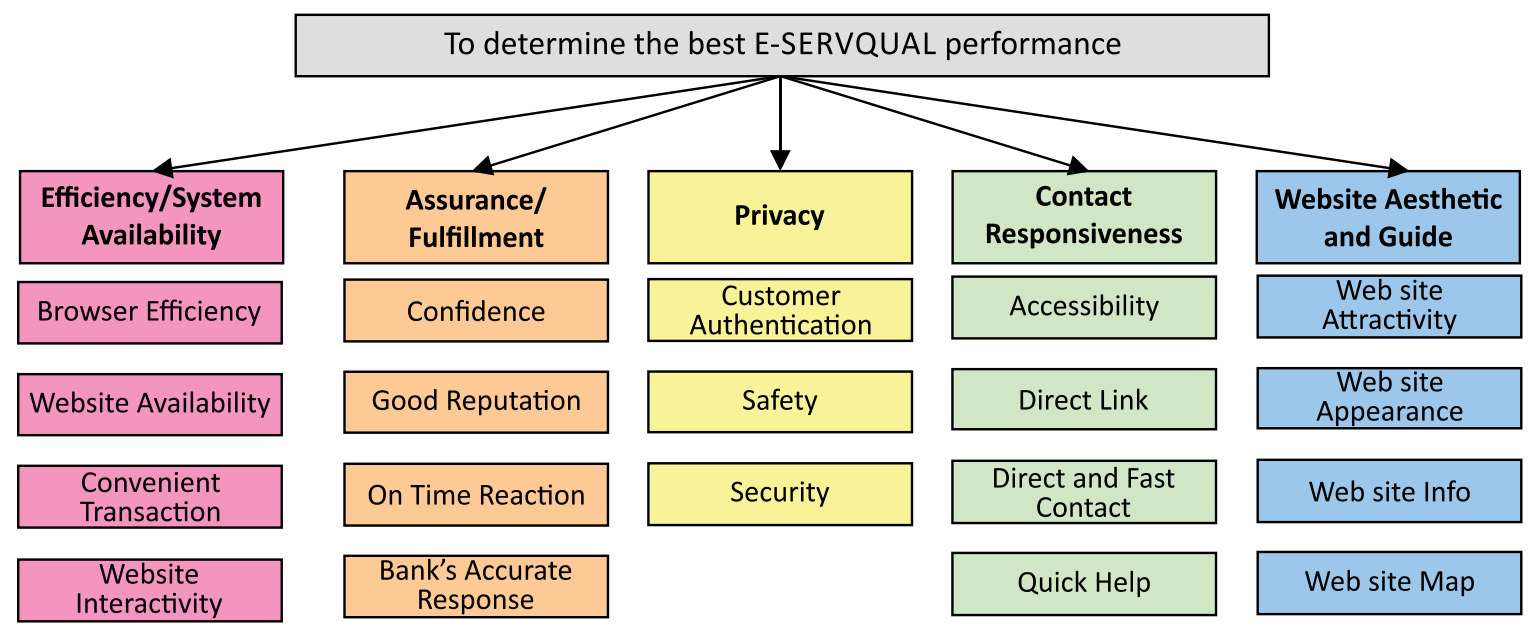

\section{ALTERNATIVES \\ $\mathrm{L}_{\mathrm{A}}=$ Vakifbank, $\mathrm{L}_{\mathrm{B}}=$ Halkbank, $\mathrm{L}_{\mathrm{C}}=$ Ziraat Bank, $\mathrm{L}_{\mathrm{D}}=$ is Bank, $\mathrm{L}_{\mathrm{E}}=$ Yapi Kredi Bank, $\mathrm{L}_{\mathrm{F}}=$ Garanti Bank}

Figure 3 Hierarchical E-Servqual model

According to the hierarchical model of our study, we have determined the web site prioritization weights of banks. Therefore, the pair-wise comparisons with linguistic and fuzzy terms are performed from the experts' judgments. At the end of the F-AHP process, the prioritization results of the e-service quality of internet based banking are obtained.

The following step after the prioritization of eSERVQUAL criteria is to classify the web sites of the alternative internet based banking. The fuzzy scale is used the same as for the AHP and the decision matrix with alternatives and criteria is carried out. In this study there are 6 internet based banking web sites in which 3 public banks and 3 private banks alternatives which belong to $L_{A}$ $=$ Vakifbank (www.vakifbank.com.tr), $\mathrm{L}_{\mathrm{B}}=$ Halkbank (www.halkbank.com.tr), $\quad \mathrm{L}_{\mathrm{C}}=$ Ziraat Bank (www.ziraat.com.tr), $\mathrm{L}_{\mathrm{D}}=$ İs Bank (www.isbank.com.tr), $\mathrm{L}_{\mathrm{E}}=$ Yapi Kredi Bank (www.yapikredi.com.tr), $\mathrm{L}_{\mathrm{F}}=$ Garanti Bank (www.garanti.com.tr). In the finalization of the methodology, the ranking of the web sites is determined. 


\subsection{Computational results}

According to the criteria set, hierarchy structure pair wise comparisons within Fuzzy-AHP local and global importance weights are obtained as given in Tab. 4 .

It is seen from Tab. 4 that the most important main criterion is "privacy" with the weight 0,437929 whereas the second criterion is "contact responsiveness" $(0,280214)$. When the bottom level of the hierarchy is examined in terms of global importance, the first three sub criteria can be sequenced as "Direct and Fast Contact $(0,096974) "$, "Confidence $(0,092457) "$, and "Convenient Transaction/WPW $(0,086191) "$. An interesting result is obtained showing that "Website Aesthetic and Guide" main criterion has no importance or any effect on selection and/or evaluation of internet banking, even if this criterion is in the E-Servqual model for evaluation. Therefore, the subcriteria of "Website Aesthetic and Guide" main criterion cannot affect further steps. In the TOPSIS methodology, after the criterion weights are obtained, these weights are distributed to the evaluation matrix consisting of alternative ratings in terms of each criterion. For this purpose simple matrix multiplication is applied as given in the Eq. (18) to obtain $\left[V_{i j}\right]$ matrix. The next step in this methodology is to define the FPIS and FNIS from $V_{i j}$ so that the distances from these solutions can be calculated. Tab. 4 represents the FPIS and FNIS values for each criterion with trapezoidal fuzzy numbers $(a, b, c, d)$, elements of which are placed in each cell.

\begin{tabular}{|c|c|c|c|}
\hline & Criterion Name & Importance level & \\
\hline Main criterion 1 & Efficiency/System Availability & 0,123357 & \\
\hline Main criterion 2 & Assurance/Fullfilment & 0,158143 & \\
\hline Main criterion 3 & Privacy & 0,437929 & \\
\hline Main criterion 4 & Contact Responsiveness & 0,280214 & \\
\hline Main criterion 5 & Website Aesthetic and Guide & 0,000000 & \\
\hline Efficiency/System Availability & Sub criteria name & Local importance level & Global importance level \\
\hline Sub criterion 11 & Browser Efficiency & 0,080357 & 0,009913 \\
\hline Sub criterion 12 & Website Availability & 0,147000 & 0,018134 \\
\hline Sub criterion 13 & Convenient Transaction/WPW & 0,698714 & 0,086191 \\
\hline Sub criterion 14 & Website Interactivity & 0,073929 & 0,009120 \\
\hline \multicolumn{4}{|l|}{ Assurance/Fullfilment } \\
\hline Sub criterion 21 & Confidence & 0,584643 & 0,092457 \\
\hline Sub criterion 22 & Good Reputation & 0,020857 & 0,003298 \\
\hline Sub criterion 23 & On Time Reaction & 0,130929 & 0,020705 \\
\hline Sub criterion 24 & Bank's Accurate Response & 0,263643 & 0,041693 \\
\hline \multicolumn{4}{|l|}{ Privacy } \\
\hline Sub criterion 31 & Customer Authentication & 0,590929 & 0,258785 \\
\hline Sub criterion 32 & Safety & 0,142714 & 0,062499 \\
\hline Sub criterion 33 & Security & 0,265929 & 0,116458 \\
\hline \multicolumn{4}{|l|}{ Contact Responsiveness } \\
\hline Sub criterion 41 & Accesibility & 0,212286 & 0,059485 \\
\hline Sub criterion 42 & Direct Link & 0,261857 & 0,073376 \\
\hline Sub criterion 43 & Direct and Fast Contact & 0,346071 & 0,096974 \\
\hline Sub criterion 44 & Quick Help & 0,179857 & 0,050399 \\
\hline \multicolumn{4}{|l|}{ Website Aesthetic and Guide } \\
\hline Sub criterion 51 & Website Attractivity & 0,067214 & 0,000000 \\
\hline Sub criterion 52 & Website Appearance & 0,116286 & 0,000000 \\
\hline Sub criterion 53 & Website Info & 0,684571 & 0,000000 \\
\hline Sub criterion 54 & Website Map & 0,131929 & 0,000000 \\
\hline
\end{tabular}

Table 5 FPIS \& FNIS Values for Each Criterion

\begin{tabular}{|l|r|r|r|r|r|r|r|r|}
\hline \multicolumn{1}{|c|}{ Criterion } & \multicolumn{2}{|c|}{ FPIS } & \multicolumn{3}{c}{ FNIS } \\
\hline Browser Efficiency & 0,008921 & 0,008921 & 0,008921 & 0,008921 & 0,000000 & 0,000000 & 0,000000 & 0,000000 \\
\hline Website Availability & 0,018134 & 0,018134 & 0,018134 & 0,018134 & 0,000000 & 0,000000 & 0,000000 & 0,000000 \\
\hline Convenient Transaction/WPW & 0,086191 & 0,086191 & 0,086191 & 0,086191 & 0,000000 & 0,000000 & 0,000000 & 0,000000 \\
\hline Website Interactivity & 0,009120 & 0,009120 & 0,009120 & 0,009120 & 0,000000 & 0,000000 & 0,000000 & 0,000000 \\
\hline Confidence & 0,092457 & 0,092457 & 0,092457 & 0,092457 & 0,000000 & 0,000000 & 0,000000 & 0,000000 \\
\hline Good Repuatiton & 0,003298 & 0,003298 & 0,003298 & 0,003298 & 0,000000 & 0,000000 & 0,000000 & 0,000000 \\
\hline On Time Reaction & 0,020705 & 0,020705 & 0,020705 & 0,020705 & 0,000000 & 0,000000 & 0,000000 & 0,000000 \\
\hline Bank's Accurate Response & 0,041693 & 0,041693 & 0,041693 & 0,041693 & 0,000000 & 0,000000 & 0,000000 & 0,000000 \\
\hline Customer Authentication & 0,258785 & 0,258785 & 0,258785 & 0,258785 & 0,051757 & 0,051757 & 0,051757 & 0,051757 \\
\hline Safety & 0,062499 & 0,062499 & 0,062499 & 0,062499 & 0,000000 & 0,000000 & 0,000000 & 0,000000 \\
\hline Security & 0,116458 & 0,116458 & 0,116458 & 0,116458 & 0,000000 & 0,000000 & 0,000000 & 0,000000 \\
\hline Accesibility & 0,059485 & 0,059485 & 0,059485 & 0,059485 & 0,000000 & 0,000000 & 0,000000 & 0,000000 \\
\hline Direct Link & 0,073376 & 0,073376 & 0,073376 & 0,073376 & 0,000000 & 0,000000 & 0,000000 & 0,000000 \\
\hline Direct and Fast Contact & 0,096974 & 0,096974 & 0,096974 & 0,096974 & 0,000000 & 0,000000 & 0,000000 & 0,000000 \\
\hline Quick Help & 0,045359 & 0,045359 & 0,045359 & 0,045359 & 0,000000 & 0,000000 & 0,000000 & 0,000000 \\
\hline Website Attractivity & 0,000000 & 0,000000 & 0,000000 & 0,000000 & 0,000000 & 0,000000 & 0,000000 & 0,000000 \\
\hline Website Appearance & 0,000000 & 0,000000 & 0,000000 & 0,000000 & 0,000000 & 0,000000 & 0,000000 & 0,000000 \\
\hline Website Info & 0,000000 & 0,000000 & 0,000000 & 0,000000 & 0,000000 & 0,000000 & 0,000000 & 0,000000 \\
\hline Website Map & 0,000000 & 0,000000 & 0,000000 & 0,000000 & 0,000000 & 0,000000 & 0,000000 & 0,000000 \\
\hline
\end{tabular}


For each value of $\left[V_{i j}\right]$, both distances from FNIS and FPIS are calculated by using vertex distance (equation 23). The distance values are given in Tab. 6 and Tab. 7 for FPIS and FNIS, respectively. When this stem has been finished the trapezoidal fuzzy numbers are defuzzificated to single values. For the next step, all distance values through each row are summed to reach the overall distance of alternatives representing evaluations in terms of all criteria for both FPIS and FNIS. Then $C C_{i}$ ratio is calculated to see the evaluation result of each alternative bank (see equation 24) and the results are given in Tab. 8.

According to the approval status scale given in Tab. 2 and the $C C_{i}$ results in Tab. 7, none of the alternatives are in "approved and preferred status". However, none of them also are in either "Do not recommend" or "Recommend with high risk". All of them are in "Recommend with low risk". The performance values are very close to each other for the alternative $\mathrm{L}_{\mathrm{F}}, \mathrm{L}_{\mathrm{D}}, \mathrm{L}_{\mathrm{E}}$ and $\mathrm{L}_{\mathrm{A}}$.

Table 6 Distances between banks and FPIS with respect to each criterion

\begin{tabular}{|c|c|c|c|c|c|c|c|}
\hline $\begin{array}{l}\text { Positive } \\
\text { Distance }\end{array}$ & $\begin{array}{c}\text { Browser } \\
\text { Efficiency }\end{array}$ & $\begin{array}{c}\text { Website } \\
\text { Availability }\end{array}$ & $\begin{array}{c}\text { Convenient } \\
\text { Transaction/WPW } \\
\end{array}$ & $\begin{array}{c}\text { Website } \\
\text { Interactivity }\end{array}$ & Confidence & $\begin{array}{c}\text { Good } \\
\text { Repuatiton }\end{array}$ & $\begin{array}{l}\text { On Time } \\
\text { Reaction }\end{array}$ \\
\hline $\mathrm{D}\left(\mathrm{L}_{\mathrm{A}}, \mathrm{A}^{*}\right)$ & 0,004314 & 0,009539 & 0,043630 & 0,004594 & 0,043548 & 0,001464 & 0,013069 \\
\hline $\mathrm{D}\left(\mathrm{L}_{\mathrm{B}}, \mathrm{A}^{*}\right)$ & 0,004541 & 0,009824 & 0,044108 & 0,004781 & 0,056421 & 0,001568 & 0,013712 \\
\hline $\mathrm{D}\left(\mathrm{L}_{\mathrm{C}}, \mathrm{A}^{*}\right)$ & 0,005764 & 0,011701 & 0,056538 & 0,006091 & 0,056862 & 0,001919 & 0,013836 \\
\hline $\mathrm{D}\left(\mathrm{L}_{\mathrm{D}}, \mathrm{A}^{*}\right)$ & 0,003762 & 0,008685 & 0,042032 & 0,004618 & 0,049311 & 0,001438 & 0,012727 \\
\hline $\mathrm{D}\left(\mathrm{L}_{\mathrm{E}}, \mathrm{A}^{*}\right)$ & 0,003930 & 0,008658 & 0,040794 & 0,004760 & 0,045656 & 0,001453 & 0,012023 \\
\hline $\mathrm{D}\left(\mathrm{L}_{\mathrm{F}}, \mathrm{A}^{*}\right)$ & 0,003853 & 0,008043 & 0,037973 & 0,004546 & 0,054847 & 0,001442 & 0,011164 \\
\hline $\begin{array}{l}\text { Positive } \\
\text { Distance }\end{array}$ & $\begin{array}{c}\text { Bank's } \\
\text { Accurate } \\
\text { Response } \\
\end{array}$ & $\begin{array}{c}\text { Customer } \\
\text { Authentication }\end{array}$ & Safety & Security & Accesibility & Direct Link & $\begin{array}{l}\text { Direct and } \\
\text { Fast Contact }\end{array}$ \\
\hline $\mathrm{D}\left(\mathrm{L}_{\mathrm{A}}, \mathrm{A}^{*}\right)$ & 0,019631 & 0,127961 & 0,030168 & 0,056853 & 0,030191 & 0,037710 & 0,051151 \\
\hline $\mathrm{D}\left(\mathrm{L}_{\mathrm{B}}, \mathrm{A}^{*}\right)$ & 0,023958 & 0,127961 & 0,036758 & 0,061456 & 0,032766 & 0,046164 & 0,064648 \\
\hline $\mathrm{D}\left(\mathrm{L}_{\mathrm{C}}, \mathrm{A}^{*}\right)$ & 0,027534 & 0,129631 & 0,041274 & 0,077731 & 0,037698 & 0,051973 & 0,070063 \\
\hline $\mathrm{D}\left(\mathrm{L}_{\mathrm{D}}, \mathrm{A}^{*}\right)$ & 0,019223 & 0,120718 & 0,029154 & 0,054279 & 0,027158 & 0,036576 & 0,049471 \\
\hline $\mathrm{D}\left(\mathrm{L}_{\mathrm{E}}, \mathrm{A}^{*}\right)$ & 0,019861 & 0,123466 & 0,029905 & 0,055513 & 0,028381 & 0,036342 & 0,050706 \\
\hline $\mathrm{D}\left(\mathrm{L}_{\mathrm{F}}, \mathrm{A}^{*}\right)$ & 0,018799 & 0,115350 & 0,028336 & 0,054803 & 0,026515 & 0,033588 & 0,051131 \\
\hline $\begin{array}{l}\text { Positive } \\
\text { Distance }\end{array}$ & Quick Help & $\begin{array}{c}\text { Website } \\
\text { Attractivity }\end{array}$ & Website Appearance & Website Info & Website Map & & \\
\hline $\mathrm{d}\left(\mathrm{L}_{\mathrm{A}}, \mathrm{A}^{*}\right)$ & 0,025250 & 0,000000 & 0,000000 & 0,000000 & 0,000000 & & \\
\hline $\mathrm{d}\left(\mathrm{L}_{\mathrm{B}}, \mathrm{A}^{*}\right)$ & 0,025250 & 0,000000 & 0,000000 & 0,000000 & 0,000000 & & \\
\hline $\mathrm{d}\left(\mathrm{L}_{\mathrm{C}}, \mathrm{A}^{*}\right)$ & 0,031281 & 0,000000 & 0,000000 & 0,000000 & 0,000000 & & \\
\hline $\mathrm{d}\left(\mathrm{L}_{\mathrm{D}}, \mathrm{A}^{*}\right)$ & 0,022103 & 0,000000 & 0,000000 & 0,000000 & 0,000000 & & \\
\hline $\mathrm{d}\left(\mathrm{L}_{\mathrm{E}}, \mathrm{A}^{*}\right)$ & 0,022365 & 0,000000 & 0,000000 & 0,000000 & 0,000000 & & \\
\hline $\mathrm{d}\left(\mathrm{L}_{\mathrm{F}}, \mathrm{A}^{*}\right)$ & 0,021637 & 0,000000 & 0,000000 & 0,000000 & 0,000000 & & \\
\hline
\end{tabular}

Table 7 Distances between Banks and FNIS with Respect To Each Criterion

\begin{tabular}{|c|c|c|c|c|c|c|c|}
\hline $\begin{array}{l}\text { Negative } \\
\text { distance }\end{array}$ & $\begin{array}{c}\text { Browser } \\
\text { Efficiency }\end{array}$ & $\begin{array}{c}\text { Website } \\
\text { Availability }\end{array}$ & $\begin{array}{c}\text { Convenient } \\
\text { Transaction/WPW } \\
\end{array}$ & $\begin{array}{c}\text { Website } \\
\text { Interactivity }\end{array}$ & Confidence & $\begin{array}{c}\text { Good } \\
\text { Repuatiton }\end{array}$ & $\begin{array}{l}\text { On Time } \\
\text { Reaction }\end{array}$ \\
\hline $\mathrm{D}\left(\mathrm{L}_{\mathrm{A}}, \mathrm{A}-\right)$ & 0,005911 & 0,010725 & 0,052741 & 0,005924 & 0,063510 & 0,002396 & 0,010128 \\
\hline $\mathrm{D}\left(\mathrm{L}_{\mathrm{B}}, \mathrm{A}-\right)$ & 0,005333 & 0,010448 & 0,052174 & 0,005412 & 0,053428 & 0,002248 & 0,010208 \\
\hline $\mathrm{D}\left(\mathrm{L}_{\mathrm{C}}, \mathrm{A}-\right)$ & 0,004797 & 0,009223 & 0,042964 & 0,004440 & 0,052971 & 0,002136 & 0,010089 \\
\hline$\overline{\mathrm{D}\left(\mathrm{L}_{\mathrm{D}}, \mathrm{A}-\right)}$ & 0,006669 & 0,012271 & 0,057494 & 0,005902 & 0,060690 & 0,002440 & 0,011855 \\
\hline $\mathrm{D}\left(\mathrm{L}_{\mathrm{E}}, \mathrm{A}-\right)$ & 0,006400 & 0,011702 & 0,056124 & 0,005765 & 0,061060 & 0,002416 & 0,011777 \\
\hline $\mathrm{D}\left(\mathrm{L}_{\mathrm{F}}, \mathrm{A}-\right)$ & 0,006511 & 0,013170 & 0,063126 & 0,005975 & 0,055146 & 0,002435 & 0,013443 \\
\hline $\begin{array}{l}\text { Negative } \\
\text { distance }\end{array}$ & $\begin{array}{l}\text { Bank's } \\
\text { Accurate } \\
\text { Response }\end{array}$ & $\begin{array}{c}\text { Customer } \\
\text { Authentication }\end{array}$ & Safety & Security & Accesibility & Direct Link & $\begin{array}{l}\text { Direct and } \\
\text { Fast Contact }\end{array}$ \\
\hline $\mathrm{D}\left(\mathrm{L}_{\mathrm{A}}, \mathrm{A}-\right)$ & 0,028635 & 0,125850 & 0,042065 & 0,077541 & 0,038441 & 0,046933 & 0,060810 \\
\hline $\mathrm{D}\left(\mathrm{L}_{\mathrm{B}}, \mathrm{A}-\right)$ & 0,023958 & 0,125850 & 0,035127 & 0,068624 & 0,033828 & 0,036009 & 0,038720 \\
\hline$\overline{\mathrm{D}\left(\mathrm{L}_{\mathrm{C}}, \mathrm{A}-\right)}$ & 0,022106 & 0,124358 & 0,033138 & 0,061126 & 0,032939 & 0,028579 & 0,036543 \\
\hline $\mathrm{D}\left(\mathrm{L}_{\mathrm{D}}, \mathrm{A}-\right)$ & 0,029181 & 0,134097 & 0,043356 & 0,080757 & 0,042035 & 0,048132 & 0,062456 \\
\hline $\mathrm{D}\left(\mathrm{L}_{\mathrm{E}}, \mathrm{A}-\right)$ & 0,028337 & 0,130840 & 0,042398 & 0,079176 & 0,040460 & 0,048412 & 0,057649 \\
\hline $\mathrm{D}\left(\mathrm{L}_{\mathrm{F}}, \mathrm{A}-\right)$ & 0,029871 & 0,141430 & 0,044438 & 0,079962 & 0,043047 & 0,051730 & 0,054470 \\
\hline $\begin{array}{l}\text { Negative } \\
\text { distance }\end{array}$ & Quick Help & $\begin{array}{c}\text { Website } \\
\text { Attractivity }\end{array}$ & Website Appearance & Website Info & Website Map & & \\
\hline $\mathrm{D}\left(\mathrm{L}_{\mathrm{A}}, \mathrm{A}-\right)$ & 0,022369 & 0,000000 & 0,000000 & 0,000000 & 0,000000 & & \\
\hline $\mathrm{D}\left(\mathrm{L}_{\mathrm{B}}, \mathrm{A}-\right)$ & 0,022369 & 0,000000 & 0,000000 & 0,000000 & 0,000000 & & \\
\hline $\mathrm{D}\left(\mathrm{L}_{\mathrm{C}}, \mathrm{A}-\right)$ & 0,019305 & 0,000000 & 0,000000 & 0,000000 & 0,000000 & & \\
\hline $\mathrm{D}\left(\mathrm{L}_{\mathrm{D}}, \mathrm{A}-\mathrm{)}\right.$ & 0,029896 & 0,000000 & 0,000000 & 0,000000 & 0,000000 & & \\
\hline $\mathrm{D}\left(\mathrm{L}_{\mathrm{E}}, \mathrm{A}-\right)$ & 0,029621 & 0,000000 & 0,000000 & 0,000000 & 0,000000 & & \\
\hline $\mathrm{D}\left(\mathrm{L}_{\mathrm{F}}, \mathrm{A}-\right)$ & 0,030419 & 0,000000 & 0,000000 & 0,000000 & 0,000000 & & \\
\hline
\end{tabular}

Table 8 Computations of $d_{i}^{*}, d_{i}{ }^{*}$ and $C C_{i}$

\begin{tabular}{|c|c|c|c|c|}
\hline Alternative & Total d $^{*}$ & Total d $^{-}$ & $\mathbf{d}^{*}+\mathbf{d}^{-}$ & $\mathbf{C C}_{\mathbf{i}}$ \\
\hline $\mathrm{L}_{\mathrm{A}}$ & 0,499073 & 0,593979 & 1,093052 & 0,543413 \\
\hline $\mathrm{L}_{\mathrm{B}}$ & 0,553916 & 0,523738 & 1,077654 & 0,485998 \\
\hline $\mathrm{L}_{\mathrm{C}}$ & 0,619897 & 0,484715 & 1,104612 & 0,438810 \\
\hline $\mathrm{L}_{\mathrm{D}}$ & 0,481254 & 0,627232 & 1,108486 & 0,565846 \\
\hline $\mathrm{L}_{\mathrm{E}}$ & 0,483812 & 0,612136 & 1,095948 & 0,558545 \\
\hline $\mathrm{L}_{\mathrm{F}}$ & 0,472025 & 0,635175 & 1,107199 & 0,573677 \\
\hline
\end{tabular}




\section{Results}

The objective of this research was to present a hybrid approach based on SERVQUAL and fuzzy TOPSIS for evaluating e-service quality of internet based banking alternatives in order to obtain to best qualified alternative that satisfies the needs and the expectations of e-users. The detailed literature and SERVQUAL scales are mentioned and then e-SERVQUAL framework was proposed for the internet based banking web sites. We develop a questionnaire for collecting data for evaluating the quality of internet based banking. After these steps, the questionnaire responses are aggregated to generate an overall performance score for measuring service quality using Fuzzy AHP and for ranking the alternatives using Fuzzy TOPSIS method. We perform AHP and TOPSIS methods in fuzzy environment for reducing the uncertainty of human decisions in assigning the evaluation of criteria. There are also many other multi criteria decision making techniques for selection of the best alternative as Analytic Network Process, DEMATEL, Electre etc. For further research, the application of techniques combined with these can be used for the service quality models and the selection of the best among the alternatives. The model proposed in this study also could be carried out to investigate the customer expectations and determine the web based service quality.

\section{References}

[1] Büyüközkan Gülçin, Çifçi Gizem. A combined fuzzy AHP and fuzzy TOPSIS based strategic analysis of electronic service quality in healthcare industry. // Expert Systems with Applications. 39, 3(2012), pp. 2341-2354. DOI: 10.1016/j.eswa.2011.08.061

[2] Chen, C-T.; Lin, C-T.; Huang, S-F. A fuzzy approach for supplier evaluation and selection in supply chain management. // International Journal of Production Economics. 102, (2006), pp. 289-301. DOI: 10.1016/j.jpe.2005.03.009

[3] Chen, M. F.; Tzeng, G. H. Combining grey relation and TOPSIS concepts for selecting an expatriate host country. // Mathematical and Computer Modelling. 40, (2004), pp. 1473-1490. DOI: 10.1016/j.mcm.2005.01.006

[4] Chang, D. Y. Applications of the Extent Analysis Method on Fuzzy-AHP. // European Journal of Operational Research. 95, (1996), pp. 649-655. DOI: 10.1016/03772217(95)00300-2

[5] Dabholkar, P. A.; Thrope, D. I.; Rentz, J. O. A measure of service quality for retail stores: scale development and validation. // Journal of the Academy of Marketing Science. 24, 1(1996), pp. 3-16. DOI: 10.1007/BF02893933

[6] Guru, C. Tailoring e-service quality through CRM. // Managing Service Quality. 13, 6(2003), pp. 20-531. DOl: 10.1108/09604520310506577

[7] Kahraman, Cengiz; Cebeci, Ufuk; Da, Ruan. MultiAttribute Comparison of Catering Service Companies Using Fuzzy AHP: The Case of Turkey. // International Journal of Production Economics. 87, (2004), pp. 171-184. DOI: $10.1016 /$ S0925-5273(03)00099-9

[8] Lasser, W. M.; Manolis, C.; Winsor, R. D. Service quality perspectives and satisfaction in private banking. // Journal of Services Marketing. 14, 3(2000), pp. 244-271. DOI: $10.1108 / 08876040010327248$
[9] Lee, Hakyeon; Kim, Chulhyun. Benchmarking of service quality with data envelopment analysis. // Expert Systems with Applications. 41, 8(2014), pp. 3761-3768. DOI: 10.1016/j.eswa.2013.12.008

[10] Lin, Wen-Bao. An empirical of service quality model from the viewpoint of management. // Expert Systems with Applications. 32, 2(2007), pp. 364-375. DOI: 10.1016/j.eswa.2005.11.033

[11] McKenzie, B. Retail service quality success factors in Estonia - a qualitative approach. // Baltic Journal of Management. 1, 3 (2006), pp. 352-369. DOI: $10.1108 / 17465260610690971$

[12] Mehte Subhash, C.; Lalwani Ashok, K.; Han Soon, Li. Service quality in retailing: relative efficiency of alternative measurement scales for different product-service environments. // International Journal of Retail \& Distribution Management. 28, 2(2000), pp. 62-72. DOI: 10.1108/09590550010315106

[13] Newman, K. Interrogating SERVQUAL: a critical assessment of service quality measurement in a high street retail bank. // International Journal of Bank Marketing. 19, 3(2001), pp. 126-139. DOI: 10.1108/02652320110388559

[14] Seth, Nitin; Deshmukh, S. G.; Vrat, P. Service quality models: a review. // International Journal of Quality \& Reliability Management. 22, 9(2005), pp. 913-949. DOl: 10.1108/02656710510625211

[15] Silvestro, R.; Cross, S. Applying service profit chain in a retail environment. // International Journal of Service Industry Management. 11, 3(2000), pp. 244-268. DOI: 10.1108/09564230010340760

[16] Siu Noel, Y. M.; Cheung Jeff, Tak-Hing. A measure of retail service. // Marketing Intelligence and Planning. 19, 2(2001), pp. 88-96. DOI: 10.1108/02634500110385327

[17] Sureshchander, G. S.; Rajendran, C.; Anatharaman, R. N. The relationship between service quality and customer satisfaction: a factor specific approach. // Journal of Services Marketing. 16, 4(2002), pp. 363-379. DOI: 10.1108/08876040210433248

[18] Tseng, Ming-Lang. A causal and effect decision making model of service quality expectation using grey-fuzzy DEMATEL approach. // Expert Systems with Applications. 36, 4(2009), pp. 7738-7748. DOI: 10.1016/j.eswa.2008.09.011

[19] Zhu, Ke-Jun; Yu, Jing; Chang, Da-Yong. Discussion on Extent Analysis Method and Applications of Fuzzy AHP. // European Journal of Operational Research. 116, (1999). DOI: 10.1016/s0377-2217(98)00331-2

[20] Tolga, E.; Demircan, M. L.; Kahraman, C. Operating System Selection Using Fuzzy Replacement Analysis and Analytic Hierarchy Process. // International Journal of Production Economics. 97, (2005), pp. 89-117. DOI: 10.1016/j.ijpe.2004.07.001

\section{Authors' addresses}

Aşkın Özdăgoğlu, Assoc. Prof. Dr.

Dokuz Eylül University, Faculty of Business,

T1naztepe Campus, Buca, İzmir, Turkey

E-mail: askin.ozdagoglu@deu.edu.tr

Mehmet Emre Güler, Assoc. Prof. Dr.

İzmir Kâtip Çelebi University, Faculty of Tourism,

Main Campus, Çiğli, İzmir, Turkey

E-mail: memre.guler@ikc.edu.tr 